\title{
Effect of lead acetate on the in vitro engulfment and killing capability of toad (Bufo arenarum) neutrophils
}

\author{
Carolina E. Rosenberg ${ }^{\mathrm{a}}$, Nilda E. Fink ${ }^{\mathrm{b}, *}$, Marcos A. Arrieta ${ }^{\mathrm{b}}$, Alfredo Salibián ${ }^{\mathrm{a}, \mathrm{c}}$ \\ ${ }^{a}$ Comisión de Investigaciones Científicas de la Provincia de Buenos Aires, La Plata B1900, Argentina \\ ${ }^{\mathrm{b}}$ Facultad de Ciencias Exactas, Departamento de Ciencias Biológicas, Universidad Nacional de La Plata, Calles 47 y 115 , \\ La Plata B1900, Argentina \\ 'Programa de Ecofisiología Aplicada, Universidad Nacional de Luján, Luján B6700ZBA, Argentina
}

Received 1 June 2002; received in revised form 28 August 2003; accepted 6 September 2003

\begin{abstract}
Lead is an element of risk for the environment and human health and has harmful effects that may exceed those of other inorganic toxicants. The immune system is one of the targets of lead. Its immunomodulatory actions depend on the level of exposure, and it has been demonstrated that environmental amounts of the metal alter immune function. Very little information is available regarding the effect of the metal on different aspects of the immune system of lower vertebrates, in particular of amphibians. The aim of this study was to investigate the effect of sublethal lead (as acetate) on the function of polymorphonuclear cells of Bufo arenarum. The results revealed that phagocytic and lytic functions of the adherent blood cells collected from sublethal lead-injected toads and incubated with suspensions of Candida pseudotropicalis were affected negatively. The decrease of the phagocytic activity was correlated with increased blood lead levels $(P<0.0001)$. Additional information referred to the total and differential leukocyte counts was presented; the only difference found was in the number of blast-like cells that resulted augmented in the samples of lead-injected toads. It was concluded that the evaluation of these parameters might be a reliable tool for the biological monitoring of the immune status of amphibians.
\end{abstract}

(c) 2003 Elsevier Inc. All rights reserved.

Keywords: Lead; Phagocytosis; Lytic activity; Candicidal activity; Polymorphonuclear cells; Neutrophils; Candida pseudotropicalis; Amphibia; Bufo arenarum

\section{Introduction}

Lead $(\mathrm{Pb})$ is an hazardous heavy metal. It is of great risk both for the environment and human health, having harmful effects that in some cases may exceed those of other inorganic toxicants. It induces a broad range of essential physiological, biochemical and behavioral dysfunctions in a doserelated fashion. The main targets of lead are

*Corresponding author. Tel.: +54-221-4235333x40; fax: + 54-221-4210059.

E-mail address: fink@biol.unlp.edu.ar (N.E. Fink). hematopoietic, nervous and renal systems; there are reports suggesting that the reproductive and immune systems are also impaired by the metal (World Health Organization, 1989, 1995).

It has been demonstrated that environmental levels of the metal may alter immune function both in vertebrates and invertebrates (Bayne, 1990; Zelikoff and Thomas, 1998). Many in vivo and in vitro studies performed on animal models, such as rat, mouse, rabbit and fish as well as those carried out in humans, made it possible to document the effects of lead on humoral and cellular immunity 
(McCabe, 1998). Important and representative immune T-cell dependent functions, such as the response to Listeria monocytogenes (Lawrence, 1981), and to sheep red blood cells (Muller et al., 1977) have been studied, however, there is not a general consensus about which are the mechanisms of action of lead on the components of the immune system (Rosenberg, 2001).

The vast majority of the studies devoted to the impact of lead on the immune system have been oriented by experimental works in mammals and research in humans. In contrast, very little information is currently available on the effect of the metal on different aspects of the immune system of lower vertebrates, in particular adult and larval amphibians (Devillers and Exbrayat, 1992; Schuytema and Nebeker, 1996; Sparling et al., 2000).

This work was based on the well-known fact that hematopoiesis is one of the main functional targets of lead and is related to our previous studies (Perí et al., 1998; Pérez Coll et al., 1988; Arrieta et al., 2000; Rosenberg, 2001; Rosenberg et al., 1998, 2002). We hypothesized that elevated blood lead concentration may be reflected in alterations of the morphology and the physiological properties of the circulating cells. Within this framework we undertook our present study focusing our attention in particular on the impact of sublethal lead on the in vitro function of the polymorphonuclear (PMN) cells. Therefore, it was of interest to investigate the effect of the metal on the phagocytic and lytic capability of the adherent cells when incubated with suspensions of Candida pseudotropicalis; we found that it was severely impaired, being the responses blood lead concentration related. Additional information referred to the effect of the metal on the total and differential leukocyte counts was also presented.

\section{Materials and methods}

\subsection{Animals}

Thirty adult Bufo arenarum male specimens were collected in the surroundings of the city of La Plata, Argentina. Animals were housed individually in plastic cages with perforated lids, containing tap-water, and were kept unfed for 7 days in a chamber at constant photoperiod and temperature (12 D: $12 \mathrm{~N}, 20{ }^{\circ} \mathrm{C}$ ); water was renewed once a day; the toads stayed in the same conditions throughout the experiments.

\subsection{Lead administration}

Two solutions, one containing lead acetate and the other containing sodium acetate were prepared in distilled water. Experimental toads $(155.8 \pm 9.5$ g, mean \pm S.E.M.; $n=15)$ received a single injection at a dose of $100 \mathrm{mg} \mathrm{kg}^{-1} \mathrm{~Pb}$ and the controls $(148.9 \pm 8.5 \mathrm{~g} ; n=15)$ were injected with $\mathrm{Na}$ acetate. The injections were performed in the dorsal lymph sac, at a rate of $1 \mathrm{ml} 160 \mathrm{~g}^{-1}$. The used dose of lead was previously determined in our laboratory as sublethal at $20{ }^{\circ} \mathrm{C}$ for toads of comparable mean body mass; it was $11.2 \%$ of the 120 h-LD50 (Arrieta et al., 1999).

\subsection{Preparation of yeast cells}

C. pseudotropicalis were cultured for $8 \mathrm{~h}$ at 37 ${ }^{\circ} \mathrm{C}$ on Sabouraud glucose agar, harvested and washed in Hank's balanced salt solution (HBSS). RPMI medium (Sigma, St. Louis MO, USA) was added up to a final concentration of $5 \times 10^{6} \mathrm{ml}^{-1}$. To opsonize the yeast cells $100 \mu$ l of pooled toad serum was added per milliliter of Candida suspension.

\subsection{Blood collection, isolation of PMN cells and determination of their phagocytic and lytic activities}

Seven days after administration of the metal, the toads were anesthesized with MS-222, double pithed and blood was obtained without anticoagulant by heart puncture. Blood was immediately spread on a glass slide as described previously (Ballart et al., 1987). After $45 \mathrm{~min}$ of incubation in a humid chamber at room temperature, the blood clot was removed and the slides were washed with RPMI medium. Under the same conditions, the cells adhering to the glass slides were incubated with $1 \mathrm{ml}$ of the Candida suspension. After $45 \mathrm{~min}$, the yeast cells remaining in suspension were removed by gently washing the slides with RPMI medium. The slides were then air dried and stained with $10 \%$ Giemsa solution. Live yeast cells were distinguished by their blue staining while the dead cells remained unstained and appeared as ghost images within the phagocyte. Phagocytic activity was expressed as the number of phagocyted Candida by 100 PMN cells checked. Lytic activity was expressed as the per- 
centage of dead yeast cells out of the total of the phagocyted Candida cells.

\subsection{Total and differential leukocytes counts}

Cells were counted in a Neubauer chamber, in whole blood diluted 1/200 in amphibian physiological solution. Results were expressed as number of cells $\times 10^{7} \mathrm{ml}^{-1}$. Differential leukocytes counts were determined in blood smears stained with May Grunwald-Giemsa. Results were expressed as absolute $\left(\times 10^{7} \mathrm{ml}^{-1}\right)$ and relative percentage values obtained from a count of at least 100 cells. Morphological identification of the cells followed the characteristics described by Varela and Sellarés (1937).

\subsection{Blood lead concentrations}

The whole blood lead concentration was determined by atomic absorption spectrometry in a Varian SpectrAA model 300 spectrometer. Aliquots of blood samples were digested with concentrated $\mathrm{HNO}_{3}$ in water-bath at $70{ }^{\circ} \mathrm{C}$ and filtered through Whatman $\mathrm{n}^{\circ} 1$ and nitrocellulose MSI 0.45 discs. The calibration curve was done adding nitrate lead solution to control samples with the same matrix as treated ones, following the specifications of the APHA-AWWA-WPCF (Clesceri et al., 1998). The detection limit was $0.1 \mathrm{mg} \mathrm{dl}^{-1}$. The linear regression for the calibration curve was $y=-0.006+0.0575 x \quad(r=0.993, P=0.007)$. All reagents were analytical grade. Data were given in $\mathrm{mg} \mathrm{dl}{ }^{-1}$, as mean \pm S.D.

\subsection{Statistical analysis}

Comparisons of the phagocytic and lytic activities of lead-treated and control toads (using Student's $t$ test), the correlation test between blood lead concentration and phagocytic activity and the normality tests were conducted using the StatgraphicsPlus software package (Manugistics Inc., Rockville MD, USA); a significance level of $P<0.05$ for the hypothesis test was used.

\section{Results}

No mortality was recorded in toads from both control and lead-injected groups; this fact was interpreted as an evidence of the tolerance of the animals to fasting for 2 weeks as well as to the administered dose of lead.

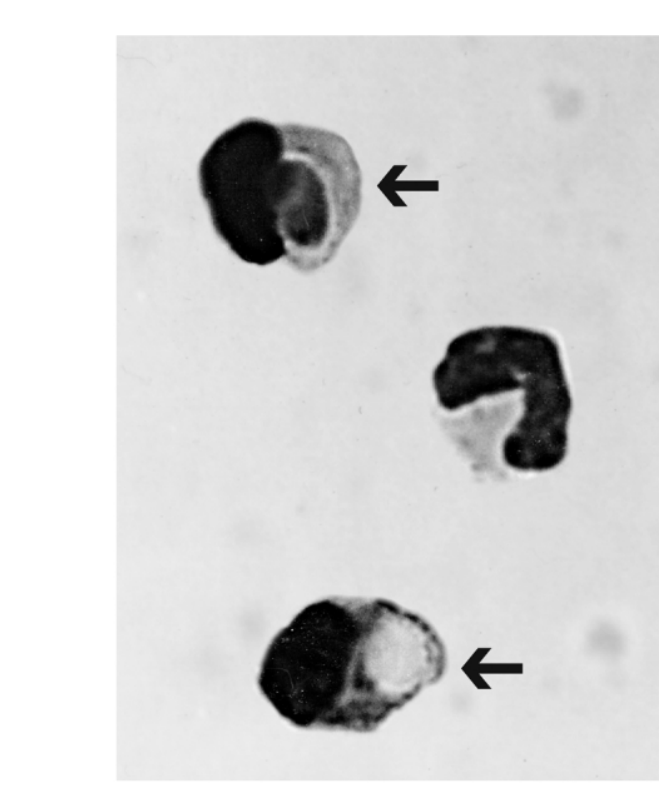

Fig. 1. PMN cells from $\mathrm{Pb}$ exposed (one week after the injection of $100 \mathrm{mg} \mathrm{kg}^{-1}$, as acetate). Non-phagocytic cell (middle), phagocytic PMN cell with a non-lysed Candida (upper), phagocytic PMN cell with a lysed Candida (lower). Arrows indicate $C$. pseudotropicalis.

\subsection{Phagocytic and lytic activities}

Compared with human cells, PMN cells of toads present similarities and differences. Like in human blood, their cytoplasm contains closely packed very fine basophilic and acidophilic granules providing the stained cell with a light pink color. However, unlikely human PMNs, the nuclei are polymorphs ranging from band to segmented forms but composed of a lower number of lobes, connected by a very narrow filament. In some cells the cytoplasm is vacuolated.

The method employed to isolate Bufo adherent cells was useful as leukocytes were not modified as in dextran fractionation or in case of using trypsin for detachment of adhesive cells. As Amphibia often develop mycotic diseases, the yeast $C$. pseudotropicalis was chosen as an indicator and also because the technique allowed to test phagocytic and lytic activity simultaneously.

In Fig. 1 smears of treated $B$. arenarum PMN cells adhered to glass $(1000 \times)$, incubated with suspensions of $C$. pseudotropicalis and stained with $10 \%$ Giemsa are shown; phagocytic and nonphagocytic cells as well as lysed and non-lysed Candida can be observed. 

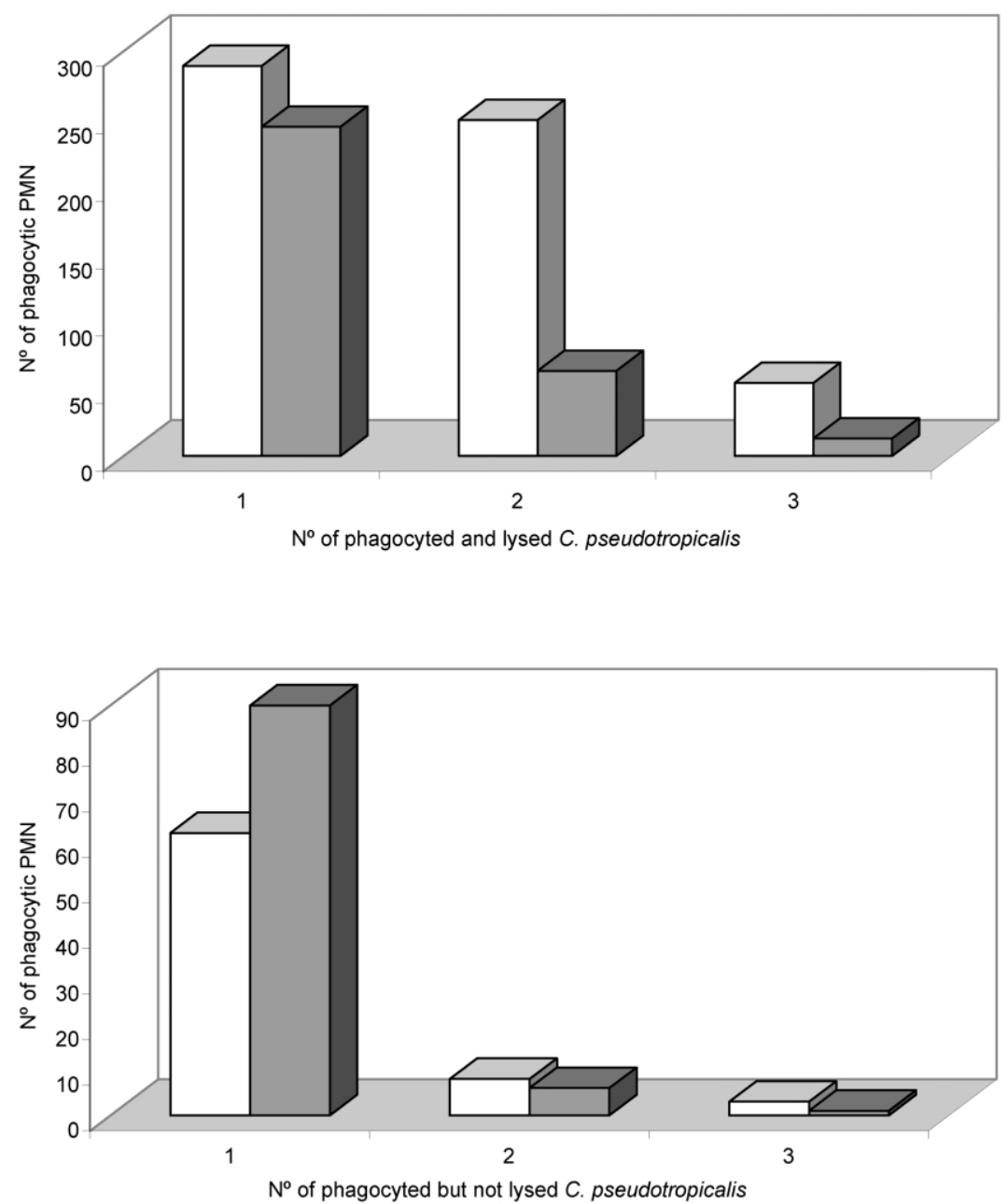

Fig. 2. Number of Candida phagocyted and lysed by PMN cells from $\mathrm{Pb}$ exposed $(n=15) 1$ week after the injection of $100 \mathrm{mg}$ $\mathrm{kg}^{-1} \mathrm{~Pb}$, as acetate, and $\square$ control toads $(n=15)$. Non-phagocytic PMN cells are not included in the figure. Upper: number of phagocyted and lysed $C$. pseudotropicalis found in each PMN. Lower: number of phagocyted but non-lysed C. pseudotropicalis found in each PMN. The bars represent the total number of PMN phapocytic cells counted in all the animals from each group $(n=15)$.

The total number of Candida phagocyted and lysed by cells from both toad groups are presented in Fig. 2; this parameter was determined counting 100 PMN cells in each smear corresponding to each one of the control or treated toads.

The absolute and relative number of phagocytic cells, phagocytic and lytic activities of both groups of animals, expressed as mean \pm S.D. are shown in Table 1. The values obtained for the phagocytic and lytic activities fitted to a normal distribution; consequently, parametric statistics comparisons could be done. In lead-injected animals, most of the evaluated parameters decreased significantly.

\subsection{Cell counts}

In Table 2 total and differential counts obtained at the end of the experiments are shown. When total and differential counts of cells of leadinjected toads were compared with those of controls, no differences were observed except in the number of blasts which was higher in the first group of toads.

\subsection{Blood lead concentrations}

Whole blood lead concentrations of control $(n=$ $15)$ and treated $(n=15)$ toads, 1 week after the 
Table 1

Comparison of relative and absolute number of phagocytic cells (PMN), phagocytic and lytic activities of Pb-exposed and control toads, 1 week after the injection of $100 \mathrm{mg} \mathrm{kg}^{-1} \mathrm{~Pb}$ (acetate)

\begin{tabular}{llll}
\hline & $\begin{array}{l}\text { Control } \\
(n=15)\end{array}$ & $\begin{array}{l}\text { Pb-exposed } \\
(n=15)\end{array}$ & $P$ \\
\hline $\begin{array}{l}\text { Phagocytic cells } \\
\quad \text { Absolute value }\left(\times 10^{7} \mathrm{ml}^{-1}\right)\end{array}$ & $0.08 \pm 0.06$ & $0.06 \pm 0.06$ & NS \\
$\quad$ Relative value $(\%)$ & $40.1 \pm 13.2$ & $21.3 \pm 8.5$ & $<0.001$ \\
Phagocytic activity & $68.9 \pm 19.3$ & $34.8 \pm 9.0$ & $<0.001$ \\
Lytic activity & $91.4 \pm 10.3$ & $81.5 \pm 15.1$ & 0.045 \\
\hline
\end{tabular}

Data expressed as mean \pm S.D. Phagocytic cells: cells that phagocyte Candida. Phagocytic activity: number of phagocyted Candida per 100 PMN cells. Lytic activity: percentage of dead yeast cells out of the total phagocyted Candida cells. NS: Non-significant.

Table 2

Total and differential blood cells counts in Pb-exposed and control toads 1 week after the injection of $100 \mathrm{mg} \mathrm{kg}^{-1} \mathrm{~Pb}$ (acetate)

\begin{tabular}{|c|c|c|c|c|c|}
\hline & \multicolumn{2}{|c|}{ Control $(n=15)$} & \multicolumn{2}{|c|}{$\mathrm{Pb}$-exposed $(n=15)$} & \multirow[t]{2}{*}{$P$} \\
\hline & $\begin{array}{l}\text { Absolute } \\
\text { value } \\
\left(\times 10^{7} \mathrm{ml}^{-1}\right)\end{array}$ & $\begin{array}{l}\text { Relative } \\
\text { value } \\
(\%)\end{array}$ & $\begin{array}{l}\text { Absolute } \\
\text { value } \\
\left(\times 10^{7} \mathrm{ml}^{-1}\right)\end{array}$ & $\begin{array}{l}\text { Relative } \\
\text { value } \\
(\%)\end{array}$ & \\
\hline Red cells & $59.90 \pm 18.60$ & & $49.10 \pm 19.50$ & & NS \\
\hline White cells & $1.13 \pm 0.57$ & & $1.68 \pm 1.19$ & & NS \\
\hline Neutrophils & $0.18 \pm 0.15$ & $14.3 \pm 8.5$ & $0.29 \pm 0.30$ & $16.6 \pm 13.4$ & NS \\
\hline Basophils & $0.04 \pm 0.06$ & $3.3 \pm 3.4$ & $0.10 \pm 0.10$ & $3.8 \pm 3.2$ & NS \\
\hline Eosinophils & $0.10 \pm 0.10$ & $9.2 \pm 5.7$ & $0.20 \pm 0.30$ & $11.0 \pm 11.3$ & NS \\
\hline Lymphocytes & $0.90 \pm 0.40$ & $71.0 \pm 9.6$ & $1.40 \pm 0.90$ & $64.0 \pm 13.6$ & NS \\
\hline Monocytes & $0.10 \pm 0.10$ & $0.3 \pm 0.8$ & $0.01 \pm 0.01$ & $0.3 \pm 0.6$ & NS \\
\hline Blast-like cells & $0.02 \pm 0.03$ & $1.9 \pm 2.6$ & $0.09 \pm 0.11$ & $4.3 \pm 4.2$ & $<0.05$ \\
\hline
\end{tabular}

Data expressed as mean \pm S.D. NS: non-significant.

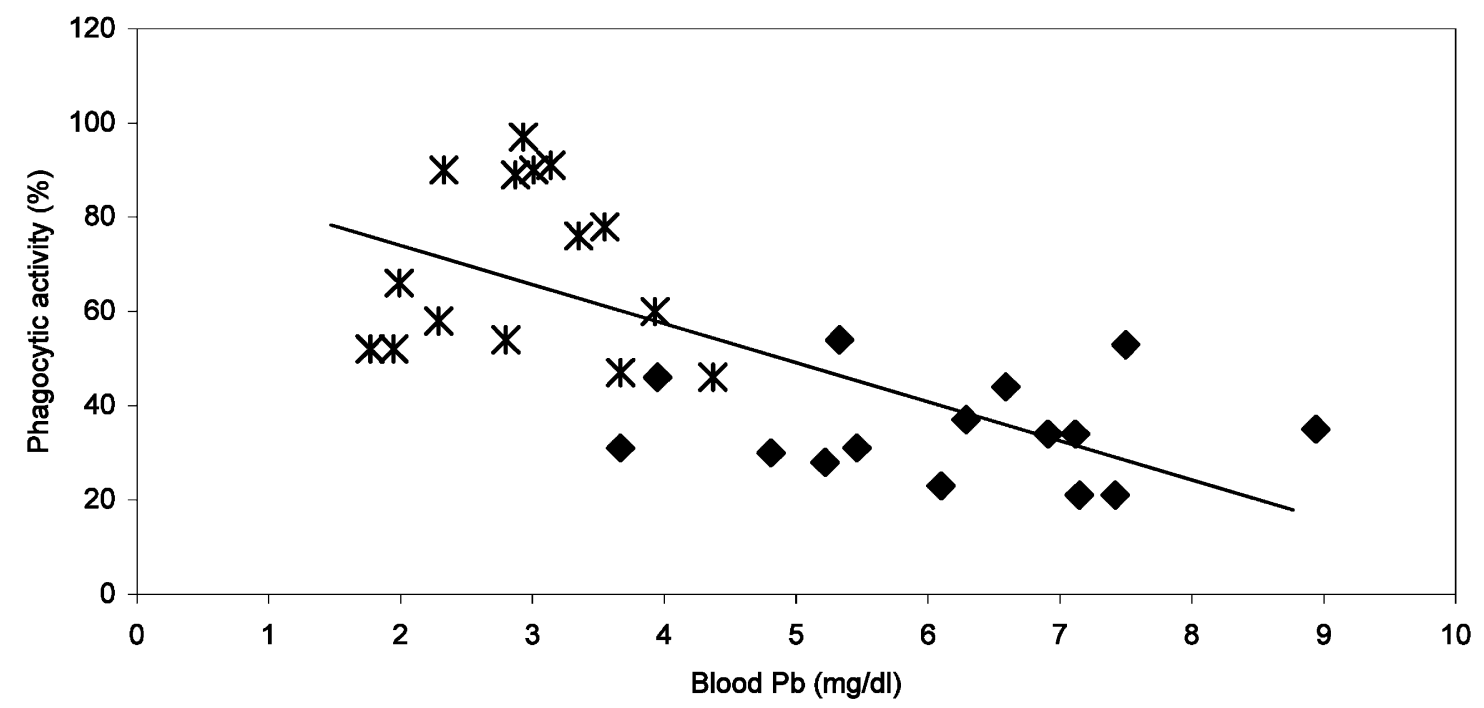

Fig. 3. Linear regression of whole blood lead $(x)$ vs. phagocytic activity $(y)$ of PMN cells from $\diamond \mathrm{Pb}$ exposed $(n=15) 1$ week after the injection of $100 \mathrm{mg} \mathrm{kg}^{-1} \mathrm{~Pb}$, as acetate, and $\star$ control toads $(n=15)$. Phagocytic activity is the number of $C$. pseudotropicalis phagocyted by 100 PMN. 
injection of $\mathrm{Na}$-acetate and $\mathrm{Pb}$-acetate solutions, expressed as mean \pm S.D. were $2.9 \pm 0.8$ and $6.2 \pm 1.4 \mathrm{mg} \mathrm{dl}^{-1}$. Fig. 3 presents the correlation between whole blood lead $(x)$ and phagocytic activity $(y)$. The regression line was $y=86.52-$ $7.47 x(r=-0.66 ; P<0.0001)$.

\section{Discussion}

The response to pathogens in Amphibia is mediated by rapid and non-specific immune system activity followed by the adaptive immune system (Du Pasquier et al., 1989; Du Pasquier, 1993, 2001). The first defense at the skin and digestive tract levels is mainly supported by anti-microbial peptides (Carey et al., 1999). Later, as in invertebrates, amphibians have phagocytes-monocytes and $\mathrm{PMN}$ - that can engulf and destroy pathogens. They also have a complement system that in the classical or alternative pathway and in antibody dependent or independent fashion can help to eliminate pathogens (Carey et al., 1999).

In relation to the assessment of PMN cells function many methods have been described, such as the study of the phagocytic and lytic activities. Phagocytosis is the active transport of extracellular particles into phagosomes (Foroozanfar et al., 1984). Once the PMN reaches its target, it must adhere to the foreign material, being this phase enhanced by opsoning substances, such immunoglobulins and complement factors. The main bactericidal mechanism of these cells is the oxygen-dependent system mediated by myeloperoxidase, which also serves as a defense against viruses and fungi. Further, myeloperoxidase-independent systems exist that can destroy certain species of fungi. Human monocytes and macrophages effectively phagocyte and lyse $C$. pseutropicalis by this type of mechanism (Ballart et al., 1987). In relation to lead intoxication studies, variable methodology was employed: phagocytic function of PMN cells was examined using a chemoluminiscent assay (L'Abbate et al., 1989). Also, PMN chemotaxis, nitroblue tetrazolium-dye reduction and the ability to kill $C$. albicans were also employed (Queiroz et al., 1993).

This is the first report on the effect of the injection of a sublethal dose of lead on the phagocytic processes of amphibian cells. The present study shows that phagocytic and lytic activities of PMN cells of lead-treated B. arenarum incubated with suspensions of $C$. pseudotropicalis were impaired one week after the injection of $100 \mathrm{mg}$ $\mathrm{kg}^{-1} \mathrm{~Pb}$ (as acetate). The phagocytic activity in toads was lower than the activity of human PMN cells (Fink de Cabutti et al., 1984), but the lytic activity was rather higher in the amphibians. This fact may indicate that the lytic process is more efficient in the group under study, possibly due to lack of more specialized mechanisms as those present in mammals.

The phagocytic activity was negatively correlated with whole blood lead at the end of the experiment. On the contrary, there was no significant correlation between lytic activity and blood lead concentration $(P=0.06)$. As regards the cell counts, no significant differences were observed, except in the number of blast-like cells. Similar observations were reported in tadpoles, where the number of red cells diminished and the number of blastic cells was higher after the exposition to the metal (Barret, 1947). In the same way, in the urodele Necturus sp., the relative values of immature cells circulating in peripheral blood augmented after the intoxication with $\mathrm{Pb}$ (Dawson, 1933).

We cannot clarify whether the blast-like cells were immature neutrophils or dividing lymphocytes. Moreover, the results of one of our early papers (Perí et al., 1998) support the possibility that those cells might be erythrocyte precursors.

Although two processes are taking place simultaneously, i.e. erythrocyte destruction and removal and erythrocyte differentiation and multiplication, the anemia progress so rapidly that the animals have practically no normal mature erythrocyte in circulating blood, therefore, there is a striking increase in the number of young and partially mature red cells (Barret, 1947).

In regard to the possible impact of different lower or higher-doses of $\mathrm{Pb}$ given to treated toads, our experience indicates that important increases or decreases in the injected amounts of the metal were not correlated by proportional changes in its concentrations in the whole blood of the animals. For instance, in another set of experiments carried out following the same experimental protocol and on the same species (Arrieta et al., 2000) we have shown that the whole blood lead concentration in toads that have been received 10,25 and $50 \mathrm{mg}$ $\mathrm{Pb} \mathrm{kg}^{-1}$ was 34,50 and $53 \mathrm{mg} \mathrm{dl}^{-1}$. In contrast, after 5 weekly injections of $\mathrm{Pb}$ to toads of the same species at a rate of $50 \mathrm{mg} \mathrm{kg}{ }^{-1}$ (Arrieta et al., in press) the whole blood metal concentration did not either show proportional increase, being 
only slightly higher than the values reported in this paper. In addition, the main changes did not occur in the blood concentration, but in the content of the hematopoietic organs of the toads (mainly liver). As it can be seen in Fig. 3, the injection of the same dose of $\mathrm{Pb}$ to all animals does not necessarily means that the concentration of the metal reached in their blood was an almost constant value.

As far as we were able to investigate, there is no direct documented evidence referring to the kinetics of lead in anurans (Linder and Grillitsch, 2000). It has long been known that bone is the major long-term site of lead accumulation. In addition, the concentration of lead in blood has been considered a useful indicator of the intensity of exposure to the metal. In the present study, the blood lead concentration obtained from our toads results elevated shortly after the administration of a very low dose relative to the LD-50; this fact could be considered as evidence in favor of a high rate of distribution of the metal after its administration.

In Amphibia the respiratory burst activity of phagocytes in whole blood of Rana temporaria was measured as zymosan induced chemiluminescence (Marnila et al., 1995). The authors showed that the temperature and thermal acclimation affected this immune parameter, since phagocyte activation was enhanced progressively at temperatures ranging from 5 to $30{ }^{\circ} \mathrm{C}$. This finding is relevant because it suggests the importance of environmental temperature on the immune system function in ectotherm species.

In general, the molecular mechanism of the $\mathrm{Pb}$ immunotoxicity appears complex and is still poorly understood. However, there are some evidences that may help to interpret our results. We have shown that at the measured concentration of lead in blood an impairment of the phagocytic and lytic activities of PMN cells occurs. This response can be partially explained by an alteration in the metabolism of lipids, as it was suggested in birds (Knowles and Donaldson, 1997) and in humans (Osterode and Ulberth, 2000). These authors showed that lead (acetate) altered eicosanoid metabolism and macrophage function in birds exposed to the metal, resulting in a diminished disease resistance. In addition, Governa et al. (1987) found an impairment of chemotactic and phagocytic activities in human lead-exposed PMN in vitro and have explained their results as a consequence of the effect of the metal on the cytoskeleton rather than on cell membrane structures. It is interesting to mention that $\mathrm{Pb}$ also alter red blood cells membrane proteins (Caspers and Siegel, 1980; Apostoli et al., 1988).

The production of reactive oxygen species may be also involved in the phagocytic process. These responses may be interpreted as the consequences of altered membrane integrity, permeability and function that, in turn, would increase the susceptibility to lipid peroxidation suggesting that lead may cause oxidative stress effects (Gurer and Ercal, 2000). In this respect, the decreased function of PMN of lead-exposed men was attributed to lower intracellular superoxide production due to mitochondria injury (Queiroz et al., 1993).

Our results show that toads constitute a group of non-mammalian vertebrates extremely resistant to lead. This fact was also shown by other authors (Birdsall et al., 1986). In regard to this point it is interesting to compare the blood concentrations of $\mathrm{Pb}$ in our toads with those found in humans; it comes out that toads were able to tolerate blood concentrations of $\mathrm{Pb}$ some 120-fold higher (López et al., 1998, 2000; Piñeiro et al., 1998).

Finally, it is worthy of mention that several authors have reported evidences showing that a number of amphibian populations are declining in many parts of the world, including Latin America (Lips et al., 2000). Concern about such declines arises because amphibians are important components of many ecosystems. Consequently, a decline in amphibian populations would have ecological consequences (Sarkar, 1996). It is accepted that the augmentation of anthropogenic pollutants in the environment as heavy metals would be one of the major factors affecting the life cycle of amphibians (Mann and Bidwell, 1999; Arrieta et al., 2001).

It is interesting that within this context it was recently suggested that both natural and man-made environmental stressors can alter amphibian immune responses, thus increasing their susceptibility to diseases (Carey et al., 1999). Considering this recent decline of amphibian populations, several patterns of mass mortality attributed to fungal or irido virus were described but the impact of enviromental factors was not completely clarified.

Our toads were sampled from the field; that origin of the animals may explain the fact that the blood of non-injected control animals contained some amount of the metal, even after keeping 
them for 2 weeks in metal-free media; it is reasonable to expect that chronically exposed animals would have developed adaptive mechanisms to compensate for negative metal impacts. Similar findings of control non-exposed or non-injected experimental groups containing measurable metal concentrations were reported by other authors (Stansley and Roscoe, 1996; Bergdahl et al., 1998; Santos et al., 1999; Berzins and Bundy, 2002). The amount of lead found in the blood of our control toads may be attributed to a complex process of environmental pollution previous to their capture on the field.

The results of the present study demonstrate that amphibians constitute a suitable experimental model for the detection of sensitive immunological parameters. In this case, the impairement of phagocytic and lytic activities of the PMN cells may be reliable indicators of the non-specific immune system status of adult $B$. arenarum.

\section{Acknowledgments}

This work was done with financial support of Comisión de Investigaciones Científicas de la Provincia de Buenos Aires, Argentina. Authors wish to thank Ms Ana María Martínez for her assistance in the preparation of this manuscript.

\section{References}

Apostoli, P., Romeo, L., De Matteis, M.C., Menegazzi, M., Faggionato, G., Vettore, L., 1988. Effects of lead on red blood cell membrane proteins. Int. Arch. Occup. Environ. Health 61, 71-75.

Arrieta, M.A., Rosenberg, C.E., Fink, N.E., Salibián, A., 1999. Toxicidad aguda del plomo para Bufo arenarum a dos temperaturas. In: X Congreso Argentino de Toxicología, La Plata (Argentina), September 27-29, 1999. Asociación Toxicológica Argentina, Buenos Aires, 56.

Arrieta, M., Peri, S., Apartin, C., Rosenberg, C., Fink, N.E., Salibián, A., 2000. ALAD activity and blood concentration of lead in Bufo arenarum. Arch. Physiol. Biochem. 108, 275-280.

Arrieta, M.A., Apartin, C., Rosenberg, C.E., Fink, N.E., Salibián, A., 2001. Blood lead content in a peri-urban population of the South American toad Bufo arenarum. Sci. Total Environ. 271, 99-105.

Arrieta, M.A., Bruzzone, L., Apartín, C., Rosenberg, C.E., Fink, N.E., Salibián, A. Biosensors of inorganic lead exposure and effect in an adult amphibian. Arch. Environ. Contam. Toxicol. (in press).

Ballart, I.J., Estevez, M.E., Diez, R.A., Sen, L., 1987. Comparison of Candida killing activity measured by chemiluminiscence and cytomorphological methods in human phagocytes. J. Immunol. Methods 97, 263-268.
Barret Jr, W.C., 1947. The effect of lead salts on the hemopoietic and hystiocytic systems of the larval frog. Am. J. Anat. 81, 117-136.

Bayne, C.J., 1990. Phagocytosis and non-self recognition in invertebrates. Bioscience 40, 723-731.

Bergdahl, I.A., Sheveleva, M., Schütz, A., Artamova, V.G., Skerfving, S., 1998. Plasma and blood lead in humans: capacity-limited binding to $\delta$-aminolevulinic acid dehydratase and other lead-building components. Toxicol. Sci. 46, 247-253.

Berzins, D.W., Bundy, K.J., 2002. Bioaccumulation of lead in Xenopus laevis tadpoles from water and sediment. Environ. Int. 28, 69-77.

Birdsall, C.W., Grye, C.E., Anderson, A., 1986. Lead concentrations in bullfrog Rana catesbeiana and green frog $R$. clamitans tadpoles inhabiting highway drainages. Environ. Pollut. A 40, 233-247.

Carey, C., Cohen, N., Rollins-Smith, L., 1999. Amphibian declines: an immunological perspective. Dev. Comp. Immunol. 23, 459-472.

Caspers, M.L., Siegel, G.J., 1980. Inhibition by lead of human erythrocyte $(\mathrm{Na}+\mathrm{K})$ Adenosine triphosphatase associated with binding of $\mathrm{Pb}$ to membrane fragments. Biochim. Biophys. Acta 600, 27-35.

Clesceri, L.S., Greenberg, A.E., Eaton, A.M. (Eds.), 1998. APHA-AWWA-WPCF: Standard Methods for the Examination of Water and Wastewater. APHA-AWWA-WPCF, Baltimore.

Dawson, A.B., 1933. An experimental study of hemopoiesis in Necturus: effects of lead poisoning on normal and splenectomized animals. J. Morphol. 55, 349-375.

Devillers, J., 1992. In: Devillers, J., Exbrayat, J.M. (Eds.), Ecotoxicity of Chemicals to Amphibians. Gordon and Reading, Philadelphia, USA.

Du Pasquier, L., 1993. Evolution of the immune system. In: Paul, W.E. (Ed.), Fundamental Immunology. Raven Press, New York, pp. 199-233.

Du Pasquier, L., 2001. The immune system of invertebrates and vertebrates. Comp. Biochem. Physiol. B 129, 1-15.

Du Pasquier, L., Schwaper, J., Flajnik, M.F., 1989. The immune system of Xenopus. Annu. Rev. Immunol. 7, 251-275.

Fink de Cabutti, E.N., Morales, V.H., Jmelnitzky, C., Basualdo Farjat, J.A., de Torres, R., 1984. Aspectos inmunológicos en portadores crónicos asintomáticos del HbsAg. Sangre 29, 370-375.

Foroozanfar, N., Melino, G., Porta, F.A., 1984. Investigation of neutrophil functions. Lab. J. Res. Lab. Med. 11, 115-120.

Governa, M., Valentino, M., Visona, I., 1987. In vitro impairment of human granulocyte functions by lead. Arch. Toxicol. 6, 421-425.

Gurer, H., Ercal, N., 2000. Can antioxidants be beneficial in the treatment of lead poisoning? Free Radical Biol. Med. 29, 927-945.

Knowles, S.O., Donaldson, W.E., 1997. Lead disrupts eicosanoid metabolism, macrophage function and disease resistance in birds. Biol. Trace Elem. Res. 60, 13-26.

L'Abbate, N., Rana, F., Cassano, F., Vaira, A., Specchia, G., Liso, V., 1989. The phagocytic activity of the neutrophilic- 
granulocytes via chemoluminescence and occupational exposure to lead. G. Ital. Med. Lav. 11, 279-282.

Lawrence, D.A., 1981. Heavy metal modulation of lymphocyte activities. Toxicol. Appl. Pharmacol. 57, 439-451.

Linder, G., Grillitsch, B., 2000. Ecotoxicology of metals. In: Sparling, D.W., Linder, G., Bishop, C.A. (Eds.), Ecotoxicology of Amphibian and Reptiles. Society of Environmental Toxicology and Chemistry Press, Pensacola, FL, pp. 325-458.

Lips, K., Young, B., Ibañez, R., Salas, A., 2000. Amphibian declines in Latin America. Froglog No. 37: 1-4.

López, M.C., Urssi, L.L., Piñeiro, A.E., Avagnina, A.M., Vidaña, G., Alvarez, S., et al., 1998. Inmunotoxicología de plomo: 4. Relación entre los niveles de complementos C3 y $\mathrm{C} 4$ y la plombemia en poblaciones mayoritariamente expuestas al plomo. Acta Toxicol. Argent. 6, 47.

López, C.M., Piñeiro, A.E., Núñez, N., Avagnina, A.M., Villamil, E.C., Roses, O.E., 2000. Thyroid hormone changes in males exposed to lead in the Buenos Aires area (Argentina). Pharmacol. Res. 42, 599-602.

Mann, R., Bidwell, J., 1999. Toxicological issues for amphibians in Australia. In: Campbell, A. (Ed.), Declines and Disappearances of Australian Frogs. Environment Australia, Canberra, pp. 185-201.

McCabe Jr, M.J., 1998. Lead. In: Zelikoff, J.T., Thomas, P.T. (Eds.), Immunotoxicology of Environmental and Occupational Metals. Taylor and Francis, London, pp. 111-129.

Marnila, P., Tiiska, A., Lagerspetz, K., Lilius, E.M., 1995. Phagocyte activity in the frog Rana temporaria: whole blood chemiluminiscence method and the effects of temperature and thermal acclimation. Comp. Biochem. Physiol. A $111,609-614$.

Muller, S., Gillert, K., Krause, C., Gross, U., L'Age-Stehr, J., Diamantstein, T., 1977. Supression of delayed type hypersensitivity of mice by lead. Experientia 33, 667-668.

Osterode, W., Ulberth, F., 2000. Increased concentration of arachidonic acid in erythrocyte membranes in chronically lead-exposed men. J. Toxicol. Environ. Health A 59, 87-95.

Pérez Coll, C.S., Herkovits, J., Salibián, A., 1988. Embryotoxicity of lead on Bufo arenarum. Bull. Environ. Contam. Toxicol. 41, 247-252.

Perí, S.I., Fink, N.E., Salibián, A., 1998. Hematological parameters in Bufo arenarum injected with subletal dose of lead acetate. Biomed. Environ. Sci. 11, 70-74.
Piñeiro, A.E., Lockhart, E., Quiroga, P.N., Schelotto, L., López, M.C., Villamil, E.C., et al., 1998. Inmunotoxicología de plomo: 5. Relación entre los niveles de las inmunoglobulinas $\mathrm{G}$, A y $\mathrm{M}$ y la plombemi en ponlaciones mayritariamente expuestas al plomo. Acta Toxicol. Argent. 6, 47.

Queiroz, M.L.S., Almeida, M., Gallao, M.I., Hoehr, N.F., 1993. Defective neutrophil function in workers occupationally exposed to lead. Pharmacol. Toxicol. 72, 73-77.

Rosenberg, C.E., Perí, S.I., Arrieta, M.A., Fink, N.E., Salibián, A., 1998. Red blood cells osmotic fragility in Bufo arenarum exposed to lead. Arch. Physiol. Biochem. 106, 19-24.

Rosenberg, C.E., 2001. Estudios hematológicos e inmunológicos en Bufo arenarum (Amphibia: Anura) expuesto al plomo. Doctoral Dissertation. National University of La Plata, Argentina.

Rosenberg, C.E., Salibián, A., Fink, N.E., 2002. An enzymelinked immunosorbent assay for measuring anti-sheep red blood cells antibodies in lead-exposed toads. J. Pharmacol. Toxicol. Methods 4, 121-128.

Sarkar, S., 1996. Ecological theory and anuran declines. Bioscience 46, 199-207.

Santos, J.L., Fontanellas, A., Morán, M.J., Enríquez de Salamanca, R., 1999. Non-synergic effect of ethanol and lead on heme metabolism in rats. Ecotoxicol. Environ. Saf. 43, 98-102.

Schuytema, G.S., Nebeker, A.V., 1996. Amphibian Toxicity Data for Water Quality Criteria Chemicals. Environmental Protection Agency, Corvallis, US EPA/600/R-96/124.

Sparling, D.W., Linder, G., Bishop, C.A. (Eds.), 2000. Ecotoxicology of Amphibian and Reptiles. SETAC Press, Pensacola, FL, USA.

Stansley, W., Roscoe, D.E., 1996. The uptake and effects of lead in small mammals and frogs at a trap and skeet range. Arch. Environ. Contam. Toxicol. 30, 220-226.

Varela, M.E., Sellares, M.E., 1937. Sobre la morfología hemática de Bufo arenarum (Hensel). Rev. Soc. Argent. Biol. 13, 345-349.

World Health Organization, 1989. Lead: Environmental Aspects. WHO, Geneva Environmental Health Criteria 85.

World Health Organization, 1995. Inorganic Lead. WHO, Geneva Environmental Health Criteria 165.

Zelikoff, J.T., Thomas, P.T. (Eds.). Immunotoxicology of Environmental and Occupational Metals. Taylor and Francis, London. 